\title{
RELATION OF PRECURARIZATION TO SUXAMETHONIUM TO PROVIDE EASE OF INTUBATION AND TO PREVENT POST-SUXAMETHONIUM MUSCLE PAINS
}

\author{
J. WIG AN D I.M. BALI
}

SuXAMEThonium is the relaxant of choice in anaesthetic practice where one desires quick muscle relaxation of short duration. As a depolarizing agent its inherent side effects of pastoperative muscle pain, ${ }^{1-4}$ increase in gastric pressure, ${ }^{5.6}$ rise in intraocular tension 7.8 and dangerous hyperkalaemia in catabolic states ${ }^{9-11}$ have led to the use of various prophylactic measures, one of which is pretreatment with a small, subparalyzing dose of non-depolarizing muscle relaxant. ${ }^{12-14.15}$

Although this method of precurarization prevents or lessens the side effects of suxamethonium, it creates the problem of difficult tracheal intubation, and the dose requirement of suxamethonium increases. ${ }^{16-19}$

The present study was aimed at finding the ideal dose combination on a body weight basis of suxamethonium with d-tubocurarine, gallamine, and pancuronium which is suitable for tracheal intubation, yet effective in appreciably reducing the post-operative muscle pains.

\section{Materials AND Method}

Two hundred and ten young healthy adults of American Society of Anesthesiologists status I, who were undergoing minor surgical procedures (tonsillectomies, dilatation and curettage, tubal ligation, herniorrhaphy and repair of hydrocele), and who were similar in age and weight (Table I) were included and were assigned at random to 21 groups of ten patients each. Premedication was avoided to permit better assessment of postoperative muscle pain and intubating conditions. Ease of tracheal intubation, visible muscle fasciculations and post-operative muscle pains were assessed by the senior author while the drugs were injected by the other author. The code was broken at the end of the study and then analyzed.

J. Wig. M.D., Lecturer; I.M. Bali, M.S. (Surg.), M.D. (Anaesth.), F.F.A.R.C.S., Ph.D., Associate Professor, Postgraduate Institute of Medical Education and Research, Chandigarh. India.

Address for correspondence; Dr. J. Wig, 11-H/7, Sector 12, P.G.I. Campus, Chandigarh-160012, India.

Canad. Anaesth. Soc. J., vol. 26, no. 2, March 1979
Suxamethonium was investigated at three dose levels of $1,1.5$ and $2 \mathrm{mg} \cdot \mathrm{kg}^{-1}$ alone as controls, or in combination with tubocurarine $\mathbf{0 . 0 5}$ and 0.07 $\left.\mathrm{mg} \cdot \mathrm{kg}^{-1}\right)$, gallamine $\left(0.2\right.$ and $\left.0.4 \mathrm{mg} \cdot \mathrm{kg}^{-1}\right)$ or pancuronium $\left(0.01\right.$ and $\left.0.02 \mathrm{mg} \cdot \mathrm{kg}^{-1}\right)$. These small doses of non-depolarizing muscle relaxants were given intravenously three minutes before suxamethonium. Induction of anaesthesia was with thiopentone 2.5 per cent $\left(5 \mathrm{mg} \cdot \mathrm{kg}^{-1}\right.$ body weight) given intravenously two minutes after precurarization, that is one minute before suxamethonium. Intubation was attempted $45 \mathrm{sec}$ onds after the suxamethonium injection and ease of intubation was graded as listed in Table 11. Visible muscle fasciculations were graded as absent, mild, moderate, or severe (Table III).

Anaesthesia was maintained with nitrous oxide 60 per cent in oxygen and further doses of the non-depolarizing muscle relaxant were used, depending upon surgical requirements. Ventilation was controlled. For post-operative analgesia, metamizole $1-1.5 \mathrm{~g}$ was administered by intramuscular injection.

Post-operative suxamethonium pains were assessed at 6,24 and 48 hours according to a set questionnaire and assigned to four different grades (Table IV). As the intensity of muscle pains was maximal at 24 hours, chi square $\left(\chi^{2}\right)$ statistical analysis was only done for pains at that time.

\section{RESULTS}

\section{Visible muscle fasciculations}

All patients in the three control groups (Figure 1) had mild to severe muscle fasciculations but pretreatment with non-depolarizing muscle relaxants reduced the incidence significantly to 10 to 20 per cent with tubocurarine $\left(\chi^{2}=12.93\right.$ and $10.21 . P=<0.001$ and $<0.01)$. Only one group in the gallamine series (gallamine $0.2 \mathrm{mg} \cdot \mathrm{kg}^{-1}$ and suxamethonium $1.5 \mathrm{mg} \mathbf{k g}^{-1}$ ) had a 10 per cent incidence of moderate fasciculations $\left(\alpha^{2}=12.93\right.$, $\mathbf{P}=<0.001$ ). Pancuronium at $0.01 \mathrm{mg} \cdot \mathbf{k g}^{-1}$ was much less effective than tubocurarine, gallamine or pancuronium $\mathbf{0 . 0 2} \mathrm{mg} \cdot \mathrm{kg}^{-1}$, and as the dose of suxamethonium was increased, the incidence of 
TABLE I

Patient Data of age and Weight. Mean \pm SD in the 21 Drug Groups (Control 3 and Trial 18). EACH Group of 10 Patients

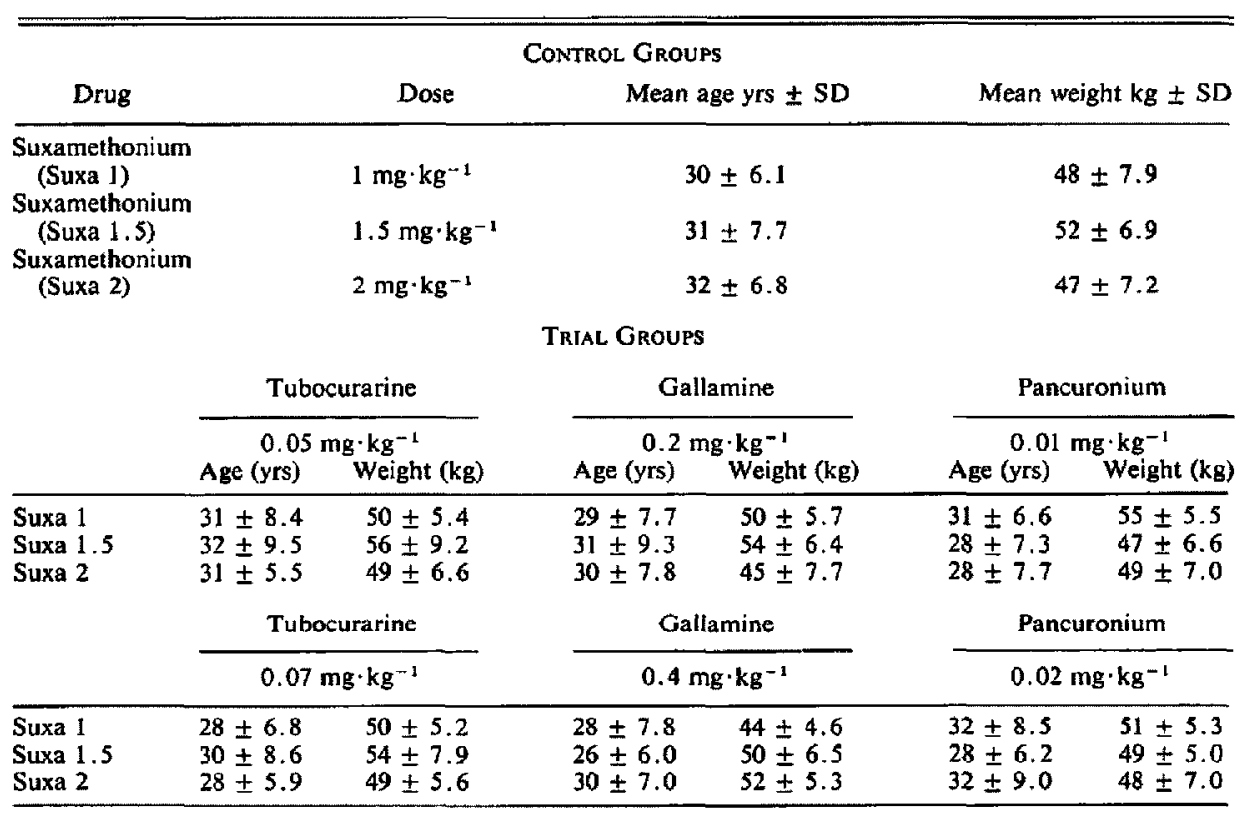

TABLE II

Grading of Difficulty of Tracheal Intubation

\begin{tabular}{ll}
\hline I & Easy and no reaction \\
II & Vocal cord movements present \\
III & Vocal cord movements and moderate reaction \\
IV & Impossible without supplementation
\end{tabular}

TABLE III

Grading of Muscle Fasciculations

\begin{tabular}{ll}
\hline Nil & Absent \\
Mild & $\begin{array}{l}\text { Fine fasciculations of the eyes, face, neck } \\
\text { or fingers without movement of the limbs }\end{array}$ \\
Moderate & $\begin{array}{l}\text { Fasciculations of greater intensity than } \\
\text { mild occurring at more than two sites or } \\
\text { movements of limbs }\end{array}$ \\
Severe & $\begin{array}{l}\text { Vigorous, sustained and widespread } \\
\text { fasciculations }\end{array}$ \\
\hline
\end{tabular}

muscle fasciculations also rose from 10 to 100 per cent (Figure 1). Pancuronium $0.02 \mathrm{mg} \cdot \mathrm{kg}^{-1} \mathrm{com}$ pletely prevented visible muscle fasciculations after suxamethonium.

\section{Ease of tracheal intubation}

Intubating conditions at 45 seconds after
TABLE IV

Grading of Post-operative Muscle Pains

\begin{tabular}{ll}
\hline Nil & Absence of pains \\
Mild & $\begin{array}{l}\text { Muscle stiffness or pains on specific } \\
\text { questioning in the nape of neck, shoulders } \\
\text { and lower chest on deep breathing }\end{array}$ \\
Moderate & $\begin{array}{l}\text { Muscle stiffness and pains complained of } \\
\text { by the patient spontaneously, requiring } \\
\text { analgesia } \\
\text { Incapacitating generalized muscle stiffness } \\
\text { or pain }\end{array}$ \\
\hline
\end{tabular}

suxamethonium were the best ( 100 per cent success) when suxamethonium was used alone at the $2 \mathrm{mg} \cdot \mathrm{kg}^{-1}$ dose level (Figure 2).

Precurarization caused a higher incidence of difficult tracheal intubations. Ideal conditions could only be achieved at higher doses of suxamethonium ( $2 \mathrm{mg} \cdot \mathrm{kg}^{-1}$ ) in combination with tubocurarine, $\left(0.07 \mathrm{mg} \cdot \mathrm{kg}^{-1}, \chi^{2}=0.56, \mathrm{P}>0.1\right)$ gallamine $\left(0.2 \mathrm{mg} \cdot \mathrm{kg}^{-1}, \chi^{2}=0.56, \mathrm{P}>0.1\right)$ and pancuronium $\left(0.01 \mathrm{mg} \cdot \mathrm{kg}^{-1}, \chi^{2}=4.27, \mathrm{P}<0.05\right.$ and $0.02 \mathrm{mg} \mathrm{kg}^{-1}, \chi^{2}=7.27, \mathrm{P}<0.01$ ). Conditions for intubation became impossible if the suxamethonium dose was kept at 1.0 or 1.5 mg $\cdot \mathrm{kg}^{-1}$ after pretreatment with tubocurarine at 


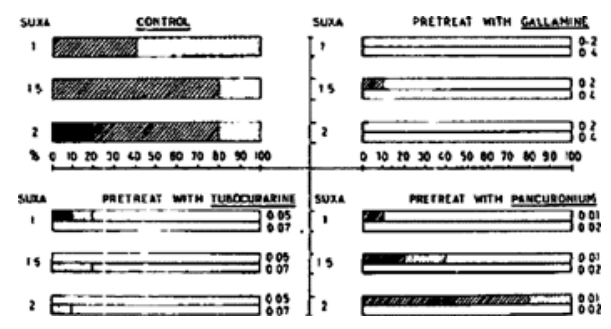

Figure 1 Showing percentage incidence of visible muscle fasciculations in control groups with suxatmethonium $1.0,1.5$ and $2 \mathrm{mg} \cdot \mathrm{kg}$ and pretreatmen groups of lubocurarine $(0.05$ and $0.07 \mathrm{mg} \cdot \mathrm{kg})$, gallamine $(0.2$ and $0.4 \mathrm{mg} \cdot \mathrm{kg})$ and pancuronium $(0.01$ and $0.02 \mathrm{mg} \cdot \mathrm{kg}$ ). Grades of fusciculations are presented as severe $\square$. moderate $\square$. mild $\square$, and nil $\square$.

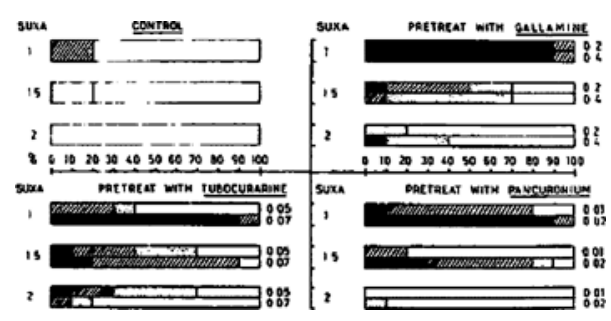

FIGURE 2 Showing percentage incidence of difficulty of tracheal intubation in control groups with suxamethonium 1.0 .1 .5 and $2 \mathrm{mg} \cdot \mathrm{kg}$ and pretreatment groups of tubocurarine $(0.05$ and $0.07 \mathrm{mg} \cdot \mathrm{kg})$, gallamine $(0.2$ and $0.4 \mathrm{mg} \cdot \mathrm{kg})$ and pancuronium $(0.01$ and $0.02 \mathrm{mg} \cdot \mathrm{kg}$ ). Grades of difficulty in intubation are represented as severe $\square$. moderate mild $\square$, and nil [.].

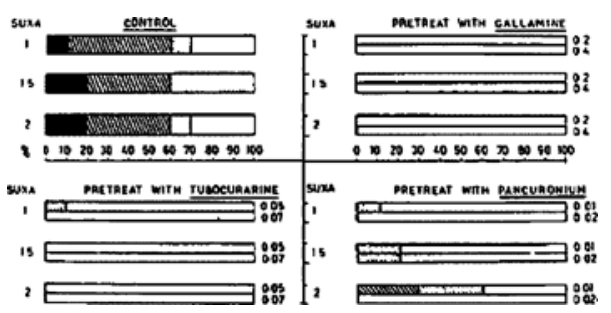

Figure 3 Showing percentage incidence of different grades of post-suxamethonium muscle pains at 24 hours after anciesthe siat in three control groups of suxamethonium 1.0, 1.5, $2 \mathrm{mg} \cdot \mathrm{kg}$ dose levels and after pretreatment with tubocurarine $(0.05$ and $0.07 \mathrm{mg} \cdot \mathrm{kg})$, gallamine $(0.2$ and $0.4 \mathrm{mg} \cdot \mathrm{kg}$ ) and pancuronium $(0.1$ and $0.2 \mathrm{mg} \cdot \mathrm{kg}$ ). Grades of pains: severe $\square$, moderate 淈, mild $\square$, and nil. $\square$.
$0.05 \mathrm{mg} \cdot \mathrm{kg}^{-1}$ and $0.07 \mathrm{mg} \cdot \mathrm{kg}^{-1}\left(\chi^{2}=10.21 \mathrm{p}=\right.$ $<0.01$ ), gallamine at $0.2 \mathrm{mg} \cdot \mathrm{kg}^{-1}$ and $0.4 \mathrm{mg} \cdot \mathrm{kg}^{-1}$

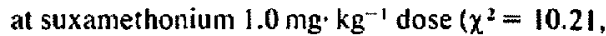
$\mathrm{P}=<0.01)$ and suxamethonium $1.5 \mathrm{mg} \cdot \mathrm{kg}^{-1}\left(\chi^{2}\right.$ $=4.27, P<0.05)$ and patncuronium at 0.02 $\mathrm{mg} \cdot \mathrm{kg}^{-1}$ dose levels $\left(\chi^{2}=10.21, P<0.01\right.$ and $\chi^{2}$ $=7.27, \mathrm{P}<0.01$ ).

\section{Post-suxamethonitum muscle pains}

Marked reduction in the incidence of postsuxamethonium muscle pains was observed in the trial groups (Figure 3). Pains were completely abolished in most of the non-depolarizing and suxamethonium combinations. Mild to moderately severe pains were seen in 10-30 per cent of cases in only five of a total of 18 trial groups.

\section{Discussion}

This study emphasizes the directly opposite effects of precurarization on the ease of tracheal intubation and post-suxamethonium muscle pains. Although the patients benefit significantly as far as pains are concerned, the anaesthetist's task of intubation is mide more difficult at the conventional dose level of $1.0 \mathrm{mg} \cdot \mathrm{kg}^{-1}$ body weight of suxamethonium. Cullen and Freund, et at. ${ }^{18.19}$ have suggested a 50 to 70 per cent increase in the dose of suxamethonium if "precurarization" exists, but the present work suggests the increase of the dose to be 100 per cent (to $2 \mathrm{mg} \cdot \mathrm{kg}^{-1}$ ) if ideal intubating conditions are to be obtained.

The best combinations of small doses of nondepolarizing agents and suxamethonium for ideal conditions of tracheal intubation and simultaneously the least post-suxamethonium muscle pain are tubocurarine $0.07 \mathrm{mg} \cdot \mathrm{kg}^{-1}$ or gallamine $0.2 \mathrm{mg} \cdot \mathrm{kg}^{-1}$ or pancuronium $0.02 \mathrm{mg} \cdot \mathrm{kg}^{-1}$ followed three minutes later by suxamethonium 2 $\mathrm{mg} \cdot \mathrm{kg}^{-1}$. The three minute time lag is very important ${ }^{18.20-22}$ as it takes this time for the proper and even distribution of curare molecules in all the neuromuscular junctions before suxamethonium arrives, and it prevents the sudden surge of generalized depolarizing potentials which are probably represented as visible muscle fasciculations.

There seems to be a correlation between the intensity and incidence of visible muscle fasciculations and post-suxamethonium muscle pains. This becomes apparent in figures 1 and 3 . The incidence of fasciculations was 100 per cent in the control group and of muscle pains 70 to 100 
per cent. Precurarization reduced the incidence of fasciculations by 10 to 40 per cent $\left(\chi^{2}=12.93\right.$ and $8.57, P=<0.001$ and $<0.01)$ and of muscle pains to $10-30$ per cent $\left(\chi^{2}=12,93\right.$ and $7.91, P=$ $<0.001$ and $<0.01$ ) except for the combination of pancuronium $0.01 \mathrm{mg} \cdot \mathrm{kg}^{-1}$ and suxamethonium $2 \mathrm{mg} \cdot \mathrm{kg}^{-1}$, where the incidence of muscle fasciculations was 100 per cent (similar to that of control gioup).

Certain factors must be kept constant if maximal advantage of precurarization is to be achieved. (1) The time interval of three minutes between non-depolarizing agent and suxamethonium. (2) The non-depolarizing muscle relaxant dose on a body weight basis. (3) Suxamethonium dose twice the conventional dose of $1 \mathrm{mg} \cdot \mathrm{kg}^{-1}$ to achieve ideal intubating conditions.

\section{SUMMARY}

Tubocurarine 0.05 and $0.07 \mathrm{mg} \cdot \mathrm{kg}^{-1}$, gallamine 0.1 and $0.2 \mathrm{mg} \cdot \mathrm{kg}^{-1}$ and pancuronium 0.01 and $0.02 \mathrm{mg} \cdot \mathrm{kg}^{-1}$ given three minutes before suxamethonium $1.0,1.5$ and $2 \mathrm{mg} \cdot \mathrm{kg}^{-1}$ in groups of 10 patients each (total 210 patients) to compare ease of tracheal intubation and incidence of post-suxamethonium muscle pain. These were compared with a control group of suxamethonium 1.0,1.5 and $2 \mathrm{mg} \cdot \mathrm{kg}^{-1}$ given alone after thiopentone $5 \mathrm{mg} \cdot \mathrm{kg}^{-1}$. On analysis, tubocurarine $0.07 \mathrm{mg} \cdot \mathrm{kg}^{-1}$ and suxamethonium 2 $\mathrm{mg} \cdot \mathrm{kg}^{-1}$ was the ideal combination with the best intubation conditions and the lowest incidence of post-suxamethonium muscle pains. The second best combination was gallamine $0.2 \mathrm{mg} \cdot \mathrm{kg}^{-1}$ and suxamethonium $2 \mathrm{mg} \cdot \mathrm{kg}^{-1}$. Pancuronium 0.01 $\mathrm{mg} \cdot \mathrm{kg}^{-1}$ and $0.02 \mathrm{mg} \cdot \mathrm{kg}^{-1}$ in combination with suxamethonium $2 \mathrm{mg} \cdot \mathrm{kg}^{-1}$ were satisfactory, although less efficient than the combination with either tubocurarine or gallamine.

\section{RÉSUMÉ}

Le but du travail était d'évaluer l'influence de la tubocurarine aux doses de 0.05 et de 0.07 $\mathrm{mg} \cdot \mathrm{kg}^{-1}$, de la gallamine $\left(0.1\right.$ et $\left.0.2 \mathrm{mg} \cdot \mathrm{kg}^{-1}\right)$ et du pancuronium $\left(0.01\right.$ et $\left.0.02 \mathrm{mg} \cdot \mathrm{kg}^{-1}\right)$ sur la facilité d'intubation et sur l'incidence des douleurs musculaires, lorsque ces agents étaient administrés trois minutes avant une injection de $1,1.5 \mathrm{et} 2 \mathrm{mg}$ de succinylcholine. Vingt-et-un groupes de dix malades ont été formés pour l'étude des différentes combinaisons. Les malades des trois premiers groupes ont reçu respectivement $1,1.5$ et $2 \mathrm{mg} \cdot \mathrm{kg}^{-1}$ de succinylcholine une minute après une injection de thiopental à raison de $5 \mathrm{mg} \cdot \mathrm{kg}^{-1}$, ce qui a permis d'établir les groupes contrôles.

C'est avec la tubocurarine à la dose de $\mathbf{0 . 0 7}$ $\mathrm{mg} \cdot \mathrm{kg}^{-1}$, associée à une dose de $2 \mathrm{mg} \cdot \mathrm{kg}^{-1}$ de succinylcholine, que l'on a trouvé les meilleures conditions d'intubation tout en notant la plus basse incidence de douleurs musculaires. Lassociation de second choix est celle de la gallamine à $0.2 \mathrm{mg} \cdot \mathrm{kg}^{-1}$ avec une dose de $2 \mathrm{mg} \cdot \mathrm{kg}^{\prime}$ de succinylcholine. Le pancuronium aux doses de 0.01 et de $0.02 \mathrm{mg} \cdot \mathrm{kg}^{-1}$ précédant la succinylcholine à $2 \mathrm{mg} \cdot \mathrm{kg}^{-1}$, a donné des résultats satisfaisants, quoiqu'inférieurs à ceux obtenus avec la tubocurarine et la gallamine.

\section{REFERENCES}

I. Bourne, J.G., Collier, H.o.J., \& Somers, G.F. Succinyl choline; muscle relaxant of short action. Lancet I: 1225-1229 (1952).

2. Churchill Davidson, H.C. Suxamethonium chloride and muscle pains. Brit. Med. J. 1: 74-75 (1954).

3. LAMOREAUX, L.F.\& URBACK, K.P. Incidence and prevention of muscle pains following the administration of succinylcholine. Anatesthesiology 21: 394-396 (1960).

4. Bush, G.H. \& Roth, F. Muscle pains after suxamethonium chloride in children. Br. J. Anaesth. 33: 151 (1961).

5. SNow, R.G. The muscle relaxants and the cardia, including the clinical management of patients likely to vomit and regurgitate. $\mathrm{Br}$. J. Anaesth. 35: 541 (1963).

6. Elliott, C.J.R. \& Sheville, E. The problem of full stomach in accident surgery. Anaesthesia. 23: $33(1968)$.

7. Dillon, J.B., Sabawala, P., Taylor, D.B., \& GUN'TER, R. Action of succinylcholine on exiraocular muscles and intraocular pressure. Anaesthesiology 18: 44 (1957).

8. KATZ, R.L. \& EAKINS, K.E. The actions of neuromuscular blocking agents on extrtocular muscle and intraocular pressure. Proc. $R$. Soc. Med. 62: 1217 (1969).

9. Belin, R.P. \& KARLEEN, C.I. Cardiac arrest in the burned patient following succinyldicholine administration. Anesthesiology. 27: $516(1966)$.

10. Roth, F. \& Wuthrich. H. The clinical importance of hyperkalaemia following suxamethonium administration. Br. J. Anaesth. 4l: 311 (1969).

II. Tовеy, R.E. Paraplegia, succinylcholine and cardiac-arrest. Anesthesiology $32: 359$ (1970).

12. WhITE, D.C. Observalions on the prevention of muscle pain after suxamethonium. Brit. J. Anaesth. 34: 332-335 (1962).

13. Glauber, D. The incidence and severity of muscle pains after suxamethonium when preceded by gal. lamine. Brit. J. Anaesth. 38: 541-544 (1966). 
14. MIL,LER, R.D. \& WAY, W.L. Inhibition of succinylcholine-induced increased intragastric pressure by non-depolarizing muscle relaxants and lidocaine. Anesthesiology 34: 185-188 (1971).

15. Domaoal, A.M., Weniger, F.C., \& Wolfson, B. "Precurarization" using Pancuronium. Anesth. Analg. 54:71-75(1975).

16. KATZ, R.L. \& KATZ, C.J. Complications associated with the use of muscle relaxants. Clin. Anesth. 2: 121-153(1966).

17. STOYNER, J. \& LUND, I. The muscle relaxants and their antagonists. A 10-year survey. Brit. J. Anaesth. 42: 235-248 (1970).

18. CULLEN, D.J. The effect of pretreatment with non-depolarizing muscle relaxants on the neuromuscular blocking action of succinylcholine. Anesthesiology 35: 572-578(1971).
19. Freund, F.G. \& Rugin, A.P. The need for additional succinylcholine after d-tubocurarine. Anesthesiology. 36: 185-188(1972).

20. KoIDE, M. \& WARD, B.E. Serum Potassium concentrations after succinylcholine in patients with renal failure. Anesthesiology 36: 142-145 (1972).

21. Burtles, R. \& TUNSTALL, M.E. Suxamethonium chloride and muscle pains. Brit. J. Anaesth. 39: 24-28(1961).

22. BALI, I.M. The influence of general anzesthetic agents and muscle relaxants on plasma potassium and other electrolytes. Ph.D. Thesis (accepted) Queen's University of Belfast, Belfast, N. Ireland. Chapt. 6, 275 (1974). 